\title{
Case of tracheal cartilage necrosis as a complication of chemoradiotherapy for oesophageal cancer
}

\author{
Susumu Noguchi, ${ }^{1}$ Sakiko Ota, ${ }^{2}$ Takakazu Sugita ${ }^{1}$
}

${ }^{1}$ Department of Respiratory Medicine, Japanese Red Cross Wakayama Medical Center, Wakayama, Japan

2Department of

Gastroenterological Medicine, Japanese Red Cross Wakayama Medical Center, Wakayama, Japan

\section{Correspondence to}

Dr Susumu Noguchi snoguchi515@gmail.com

Accepted 28 February 2016

\section{DESCRIPTION}

A 50-year-old man presented with cough, fever and dyspnoea. He had received chemoradiotherapy for oesophageal cancer 5 months previously (radiotherapy: $59.4 \mathrm{~Gy}$; chemotherapy: 5 -fluorouracil $\left(700 \mathrm{mg} / \mathrm{m}^{2}\right.$ days $\left.1-5\right)+$ cisplatin $\left(70 \mathrm{mg} / \mathrm{m}^{2}\right.$ day 1$)$ every 4 weeks for 3 cycles), and had been undergoing chemotherapy to prevent recurrence (docetaxel, $70 \mathrm{mg} / \mathrm{m}^{2} \times 90 \%$ dose).

On physical examination, his vital signs were found to be within normal limits and stridor was heard during inspiration. CT of the chest revealed tracheal stenosis (figure 1). On further examination using a flexible bronchoscopy, mucosal necrosis and a white structure protruding from the trachea were revealed (figure 2). Both the main bronchi were almost normal. We removed the protruding mass,

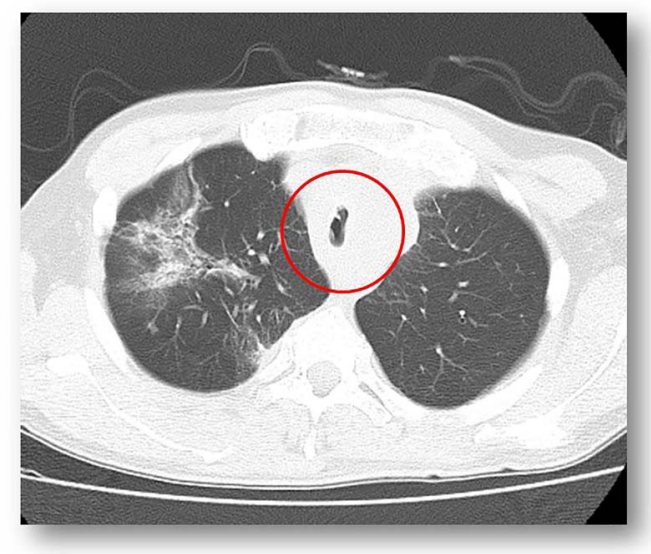

Figure 1 CT of the chest revealing tracheal stenosis.

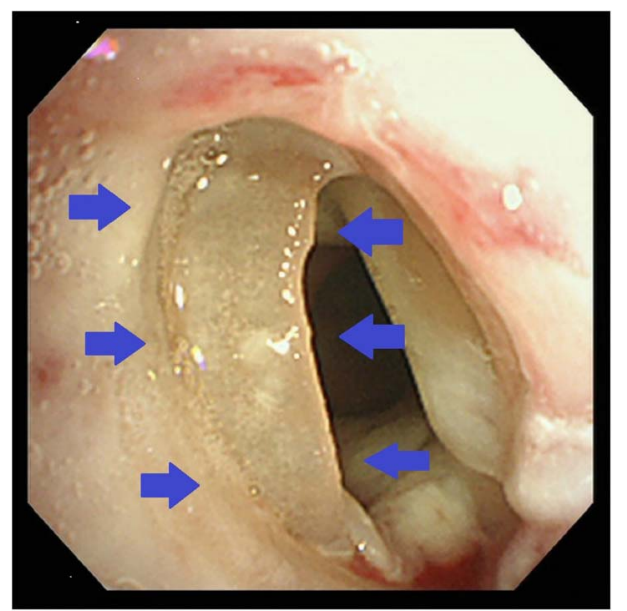

Figure 2 Tracheal cartilage protruding into the trachea.

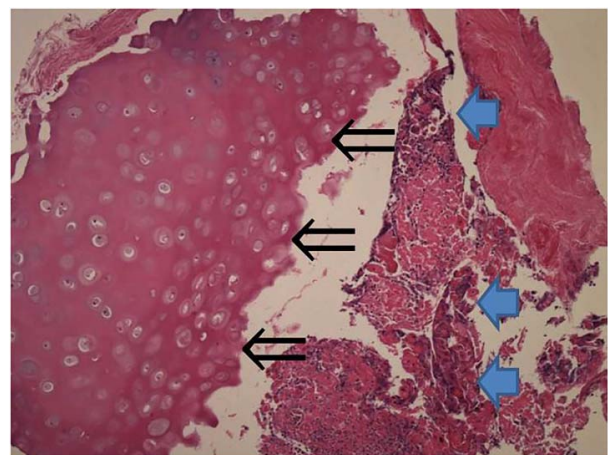

Figure 3 Histopathological analysis showing tracheal cartilage necrosis $(\Leftarrow)$ and atypical cells, which seem to be cancer $(\leftarrow)$.

which was soft and easily removed using gripping forceps, after which the patient's symptoms improved. Histopathological analysis of the resected mass showed tracheal cartilage necrosis and atypical cells (figure 3).

Perichondritis and chondronecrosis of the trachea are well-recognised complications following radiation treatment, although they can also be caused by cervical and upper mediastinal surgeries. ${ }^{12}$ Airway narrowing is observed a few months to years after radiation treatment. The dose, port and frequency of treatment, and the stage of the tumour affect any resultant necrosis.

Because of the presence of important organs and large vessels around the lungs, therapeutic interventions usually are limited to bronchial dilation and placement of a silicone stent.

In this case, we unconventionally observed the tracheal cartilage necrosis, and showed that it is possible to alleviate its symptoms by resecting the necrotic lesion.

\section{Learning points}

- Tracheal cartilage was observed in the trachea.

- Radiation treatment and chemotherapy may cause perichondritis and chondronecrosiseven treatment for oesophageal cancer-and necrotic tracheal cartilage may protrude in the trachea.

- Necrotic tracheal cartilage itself can cause airway constriction, possibly resulting in respiratory discomfort and symptoms, which can be improved by removing the necrotic tracheal cartilage. 
Contributors SO acted as the attending physician and was responsible for the management of the patient, including giving anticancer drug treatment and radiation therapy. TS was responsible for bronchoscopy and respiratory medicine, and issued the instruction for inspection. SN, the guarantor, wrote the article, performed bronchoscopy and explained the results to the patient and his family.

Competing interests None declared.

Patient consent Obtained.
Provenance and peer review Not commissioned; externally peer reviewed.

\section{REFERENCES}

1 Alraiyes A, Alraies M, Abbas A. Radiation-associated airway necrosis. Ochsner J 2013;13:273-5.

2 Michelle R, Joseph G, Mark S, et al. Nontraumatic disruption of the fibrocartilaginous trachea. Chest 2006;130:1143-9.

Copyright 2016 BMJ Publishing Group. All rights reserved. For permission to reuse any of this content visit http://group.bmj.com/group/rights-licensing/permissions.

BMJ Case Report Fellows may re-use this article for personal use and teaching without any further permission.

Become a Fellow of BMJ Case Reports today and you can:

- Submit as many cases as you like

- Enjoy fast sympathetic peer review and rapid publication of accepted articles

- Access all the published articles

- Re-use any of the published material for personal use and teaching without further permission

For information on Institutional Fellowships contact consortiasales@bmjgroup.com

Visit casereports.bmj.com for more articles like this and to become a Fellow 